\title{
Liver damage with reversible portal hypertension from vitamin A intoxication: demonstration of Ito cells
}

\author{
P GUARASCIO, B PORTMANN, G VISCO*, ROGER WILLIAMS \\ From the Liver Unit, King's College Hospital and Medical School, Denmark Hill, London, SE5 and the \\ *Ospedale L Spallanzani, Via Portuense 292, Rome
}

SUMMARY A patient with sudden onset of ascites and hepatosplenomegaly made a complete recovery after vitamin A was withdrawn. Fluorescence microscopy on embedded tissue provided a simple method of demonstrating the accumulation of fat storage (Ito) cells in the liver.

Liver involvement is mentioned in 15 of 25 cases of chronic vitamin $\mathrm{A}$ intoxication reported in adults, ${ }^{1-19}$ but detailed histological study is documented in only a few. The changes described range from apparently normal liver microscopy to fibrosis and an established cirrhosis. ${ }^{810-1214-1720}$ Five patients 8111517 are reported with evidence of portal hypertension. In two this appeared to be due to perisinusoidal accumulation of both fat-storage (Ito) cells and collagen, ${ }^{11}$ and one who progressed to cirrhosis over a five year period had continued vitamin $\mathrm{A}$ ingestion. ${ }^{16}$ Cirrhosis was present in two of the other three ${ }^{817}$ and in the one patient reported by Kistler, Ito cell accumulation was the main histological feature. All signs of portal hypertension disappeared after withdrawal of vitamin $A . .^{15}$

In the female patient described here, who presented with ascites and hepatosplenomegaly, complete recovery was observed after discontinuation of the vitamin A preparation, and a simple technique for the demonstration of Ito cells by fluorescence microscopy in paraffin-embedded sections is also reported.

\section{Case report}

A 35-year-old woman clerk became ill after sunbathing in June 1981 with anorexia and fever. Within a few days she developed ear pain, extensive desquamation of the skin and complete loss of body hair except in the axillae, together with a sudden swelling of the abdomen. Examination in July showed gingivostomatitis and cheilosis. She was

Accepted for publication 8 February 1983 suntanned but not jaundiced. Axillary lymph nodes were enlarged and soft. There was slight ankle oedema and marked ascites, with a firm liver palpable $8 \mathrm{~cm}$ below the costal margin and the tip of the spleen was easily detectable.

Laboratory data showed normal serum bilirubin, serum AST, serum ALT and electrophoretic pattern; $\gamma$ GT (77 mU/ml; normal range 4-18) and alkaline phosphatase $(240 \mathrm{mU} / \mathrm{ml}$; normal range 60-170) were slightly raised. Markers of hepatitis A and $B$ viruses, as well as autoantibodies, were not found in the serum. A liver ultrasound scan confirmed hepatosplenomegaly and ascites. Scintiscanography with ${ }^{156} \mathrm{Au}$ showed the liver and spleen to be enlarged with a patchy hepatic uptake.

Treatment was started with spironolactone (100 $\mathrm{mg} /$ day) and frusemide (20 mg/week), and the patient's condition gradually improved over the next two months, with complete disappearance of the ascites and reduction in size of the liver and spleen, which was confirmed by ultrasonography and ${ }^{199} \mathrm{Tc}$ sulphur colloid scan. When referred to King's College Hospital in October 1981 the patient appeared well, with new growth of body hair, and the spleen and liver were not palpable.

\section{HISTOLOGICAL APPEARANCES}

A percutaneous liver biopsy which had been obtained in September 1981 showed surprisingly mild abnormalities on haematoxylin and eosin stained sections. There was an increase in mixed inflammatory cells throughout the parenchyma and in places cells with microvesicular cytoplasm and indistinct boundaries occupied the sinusoid spaces. On chromotrope aniline blue stained sections, these cells appeared more numerous and better defined, 


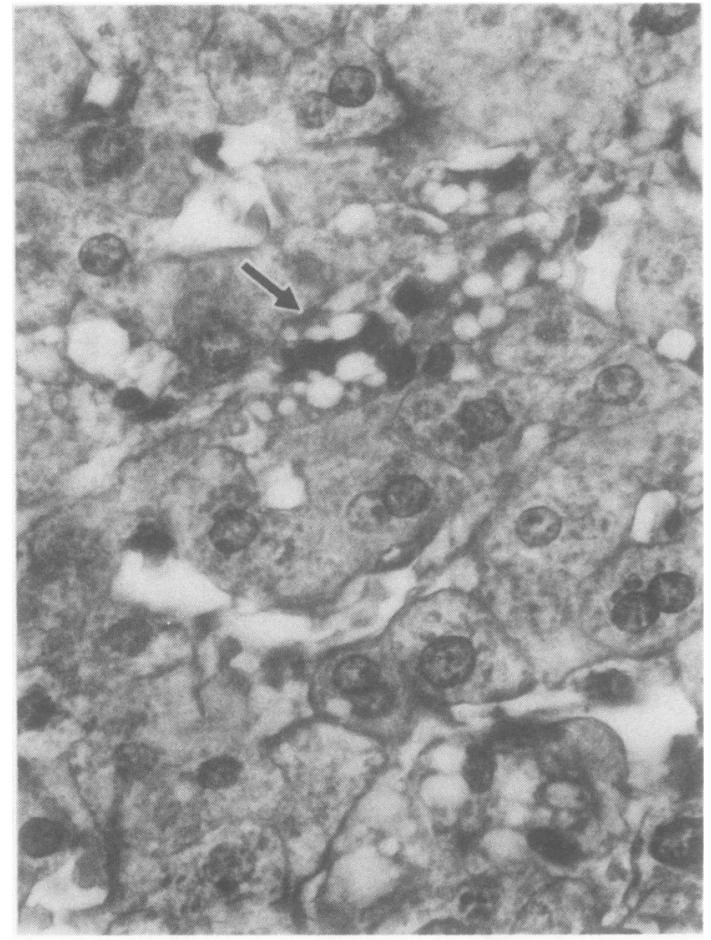

Fat storage cells occupying sinusoidal spaces (one arrowed). (a) Chromotrope aniline blue $\times 360$ (b) Fluorescence $\times 400$.

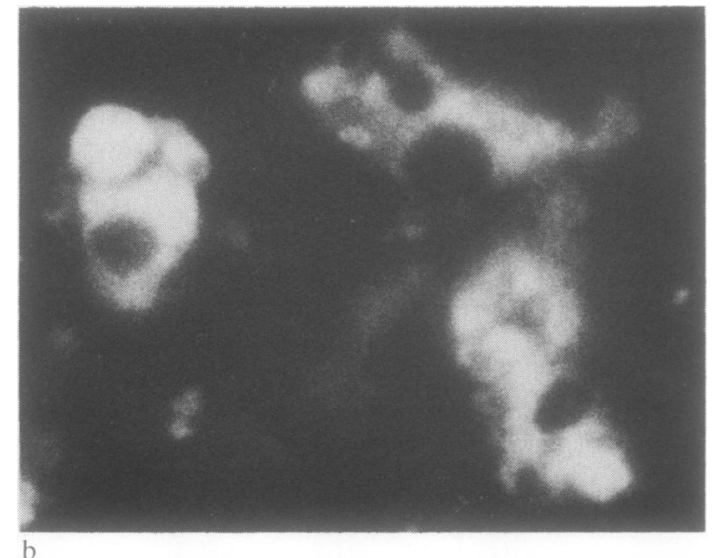

owing to the demonstration of collagen fibrils deposited at their periphery and the blue colour of their vacuolated cytoplasm which contrasted clearly with the granular red-violet staining of liver cell cytoplasm (Fig 1a). Their sinusoidal location and appearances were characteristic of fat storage (Ito) cells. ${ }^{21}$ These cells were better demonstrated when unstained deparaffinised sections were examined under ultra-violet light, as the bright fluorescence of their cytoplasm contrasted with negatively stained fatty microvesicles (Fig 1b). The hepatocytes appeared normal apart from the presence of lipofuscin in the cytoplasm.

INTAKE OF VITAMIN A

On questioning the patient further, she admitted taking a preparation of vitamins $A$ and $E$ regularly to enhance her suntan, in addition to drinking approximately half a litre of carrot juice daily throughout the year. The estimated intake of vitamin A was 90000 IU daily for two years, and this dose was increased to 300000 IU daily from May to July each year. She had stopped the tablets of her own accord when her abdomen had started to swell.

\section{Discussion}

Hair loss, desquamation, cheilosis, gingivitis, otitis, epistaxis and lymphadenopathy, quite apart from the liver lesion, are characteristic of chronic vitamin A intoxication. ${ }^{1213}$ The estimated dose of 90000 to 300000 IU daily taken by the patient during the two year period immediately before her presentation, is well above the minimum dosage of 50000 IU daily for 18 months reported to be toxic. ${ }^{9}$ The surprisingly sudden onset of ascites and hepatosplenomegaly may be ascribed to the increase in dosage of vitamin $\mathrm{A}$ taken by the patient during the summer period. Intensive sun exposure before the onset of symptoms may well have played an additional role in view of the property of the vitamin A molecule to absorb and be activated by ultraviolet light. ${ }^{22}$

The appearance of ascites was almost certainly related to the development of portal hypertension. Russel et al $^{1123}$ suggested that the accumulation of an excessive amount of vitamin $A$ in the fat storage cells resulted in their bulging into sinusoids, leading to obstruction of blood flow. This hypothesis has been confirmed experimentally in the rat by Ikejiri and Tanikawa. ${ }^{24}$ They showed that ingestion of large doses of vitamin A resulted in hypertrophy and proliferation of the fat-storage cells and a $50 \%$ decrease in volume of the sinusoids, with a consequent increase in the portal venous resistance and portal hypertension. These fat-storage cells, originally described by Ito ${ }^{21}$ and designated lipocytes by Bronfemajer ${ }^{25}$ may also play a role in the fibrogenesis of chronic liver injury by transformation into fibroblasts and production of collagen. ${ }^{26}$ In those cases who continued to take vitamin $\mathrm{A}$ the progression to cirrhosis is well documented.

The early histological changes and the specific 2 abnormalities in Ito cells are easily overlooked. In 
this case the fat-storage cells were better demonstrated on both chromotrope aniline blue stained sections and unstained deparaffinised sections examined under ultraviolet light. The considerable advantage of these techniques is that they can be performed retrospectively. The bright fluorescence thus obtained in the cytoplasm of Ito cells was unrelated to vitamin A which must have been removed during paraffin embedding, and both its colour and persistence differed markedly from the vitamin A fluorescence obtained on frozen sections. ${ }^{22}$

From the reported cases of vitamin A intoxication Olivier ${ }^{13}$ calculated that there was a delay of up to seven years between the onset of symptoms and the time of diagnosis. Doctors, as well as patients, are usually unaware of the toxic effect of vitamin A overdose and its multi-systemic manifestations are misleading in that they can mimic other diseases. ${ }^{91213}$ With early diagnosis complete reversal of the abnormalities can be obtained, which raises the question of whether a health warning should accompany preparations containing vitamin $\mathrm{A}$.

\section{References}

' Sulzeberger MB, Lazar MP. Hypervitaminosis A. Report of a case in an adult. JAMA 1951;146:788-93.

${ }^{2}$ Shaw EW, Niccoli JZ. Hypervitaminosis A. Report of a case in an adult male. Ann Intern Med 1953;39:131-4.

${ }^{3}$ Bifulco E. Vitamin A intoxication. Report of a case in an adult. $N$ Engl J Med 1953;248:690-2.

4 Gerber A, Raab AP, Sobel AE. Vitamin A poisoning in adults with description of a case. Am J Med 1954;16:729-45.

${ }^{5}$ Elliott RA, Dryer RI. Hypervitaminosis A. Report of a case in an adult. JAMA 1956;161:1157-9.

- Morrice G, Havener WH, Kapetansky F. Vitamin A as a cause of pseudotumour cerebri. JAMA 1960;173:1802-5.

' Bergen SS, Roels OA. Hypervitaminosis A. Report of a case. Am J Clin Nutr 1965;16:265-9.

- Tholen W, Paquet KJ, Rohner HG, Albrecht M. Leberzirrhose und Oesophagusvarizenblutung als Folge einer chronischen Vitamin A Intoxikation. Leber Magen Darm 1980;10:193-7.

- Stimson WH. Vitamin A intoxication in adults. Report of a case with summary of the literature. N Engl J Med 1961;265:36973.
${ }^{10}$ Soler-Bechara J, Soscia JL. Chronic hypervitaminosis A. Report of a case in an adult. Arch Intern Med 1963;112:462-6.

"Russel RM, Boyer JL, Bagheri SA, Hruban Z. Hepatic injury from chronic hypervitaminosis A resulting in portal hypertension and ascites. $N$ Engl $J$ Med 1974;291:435-40.

${ }_{12}$ Muenter MD, Perry HO, Ludwig J. Chronic vitamin A intoxication in adults. Hepatic, neurologic, and dermatologic complications. Am J Med 1971;50:129-36.

${ }^{13}$ Oliver TK. Chronic vitamin A intoxication. Report of a case in an older child and review of the literature. Am J Dis Child 1958;95:57-68.

${ }^{14}$ Lane BP. Hepatic microanatomy in hypervitaminosis $\mathbf{A}$ in man and rat. Am J Pathol 1968;53:391-8.

${ }^{15}$ Kistler HJ, Pluer S, Dickenmann W, Pirozynski W. Portale hypertonie ohne Leberzirrhose bei chronischer Vitamin A Intoxication. Schweiz Med Wochenschr 1977;107:825-32.

16 Jacques EA, Buschmann RJ, Laydent J. The histopathologic progression of vitamin $\mathrm{A}$ induced hepatic injury. Gastroenterology 1979;76:599-602.

${ }^{17}$ Fleishmann R, Shlote W, Schonerus H, Wolburg H, CastrillonOberndorfer L, Hoensch H. Kleinknotige Leberzirrhose mit ausgeprägter portaler Hypertension als Folge einer Vitamin A Intoxikation bei Psoriasis-behandlung. Deutsch Med Wochenschr 1977;102:1637-40.

${ }^{18} \mathrm{Di}$ Benedetto RJ. Chronic hypervitaminosis $\mathrm{A}$ in an adult. JAMA 1967;201:700-2.

19 Smith RF, Goodman DWS. Vitamin A transport in human vitamin A toxicity. $N$ Engl J Med 1976;294:805-8.

${ }^{20}$ Rubin E, Florman AL, Degnan T, Diaz J. Hepatic injury in chronic hypervitaminosis A. Am J Dis Child 1970;119:132-8.

${ }^{21}$ Ito I, Nemoto M. Ueber die Kupfferschen Sternzellen und die "Fettspeicherungszellen" (fat storing cells) in der Blutkapillarenwand der menschlichen Leber. Okajimas Folia Anat Jpn 1952;24:243-58.

22 Popper $\mathrm{H}$. Histologic distribution of vitamin $\mathbf{A}$ in human organs under normal and under pathologic conditions. Arch Pathol 1941;31:766-802.

${ }^{23}$ Hruban Z, Russell RM, Boyer JL, Glagov S, Bageri SA. Ultrastructural changes in livers of two patients with hypervitaminosis A. Am J Pathol 1974;76:451-68.

24 Ikejiri N, Tanikawa K. Effects of vitamin A and estrogen on the sinusoidal cells in the rat liver. In: Wisse E, Knook DL, eds. Kupffer cells and other liver sinusoidal cells. Amsterdam: Elsevier/North Holland Biomedical Press, 1977:83-92.

${ }^{25}$ Bronfemajer S, Schaffner F, Popper H. Fat storing cells (lipocytes) in human liver. Arch Pathol 1966;82:447-53.

${ }^{26}$ Kent G, Inouye T, Minick OT, Bahu RM. Role of lipocytes (perisinusoidal cells) in fibrogenesis. In: Wisse E, Knook DL, eds. Kupffer cells and other liver sinusoidal cells. Amsterdam: Elsevier/North Holland Biomedical Press, 1977:73-82.

Requests for reprints to: Dr R Williams, Liver Unit, King's College Hospital Medical School, Denmark Hill, London SE5 8RX, England. 